Dr GORAN LATINOVIĆ, docent

Filozofski fakultet Univerziteta u Banjoj Luci

Bulevar vojvode Petra Bojovića 1a

Banja Luka, Republika Srpska

goran.latinovic@unibl.rs

originalan naučni rad

UDK 94:327(497.1:450)"1919/1929"(093.2)

347.795.3(497.1:450)"1919/1929"(093.2)

primljeno: 12. januar 2017.

339.56(497.1:450)"1919/1929"(093.2)

prihvaćeno: 17. maj 2017.

341.241.8(497.1:450)"1919/1929"(093.2)

\title{
JUGOSLOVENSKO-ITALIJANSKO POMORSKO RIVALSTVO NA JADRANSKOM MORU 1919-1929.
}

\begin{abstract}
APSTRAKT: U članku se govori o rivalstvu između jugoslovenske i italijanske trgovačke mornarice i između jugoslovenskih i italijanskih luka na Jadranskom moru, u periodu od deset godina, to jest od okončanja Prvog svjetskog rata i početka pregovora o podjeli austrougarske trgovačke flote 1919. do početka Svjetske ekonomske krize 1929. Rad je napisan uglavnom na osnovu neobjavljene građe iz Centralnog državnog arhiva i Istorijsko-diplomatskog arhiva Ministarstva inostranih poslova u Rimu kao i Arhiva Jugoslavije $u$ Beogradu. Dostupna literatura, starija i novija, korišćena je prevashodno za uvodni dio u kojem je riječ o glavnim obilježjima jugoslovensko-italijanskih političkih i ekonomskih odnosa tokom dvadesetih godina 20. vijeka.
\end{abstract}

KLJUČNE RIJEČI: Kraljevina Srba, Hrvata i Slovenaca, Italija, rivalstvo, Jadransko more, trgovinska razmjena, trgovačka mornarica, pomorski i lučki saobraćaj

Kraljevina Italija bila je, zvanično, saveznik Kraljevine Srbije za vrijeme Prvog svjetskog rata. Imajući, međutim, u vidu koliko su se razlikovali interesi dviju država, možda ne bi bilo pretjerano reći da je tolika razlika bila jednaka onoj između zaraćenih i neprijateljskih država. ${ }^{1}$ U stvari, u Italiji su postojala dva suprotstavljena pogleda na jugoslovensko pitanje: 1) potpuna dominacija Italije na Jadranskom moru i njeno teritorijalno proširenje na istočnu obalu Jadrana i 2) kompromis sa Južnim Slovenima radi rušenja Austro-Ugarske i stvaranja nacionalnih država na njenim ruševinama, $\mathrm{u}$ tradicionalnom duhu rizorđimenta i Macinija. ${ }^{2}$ Italijanska vlada zaključila je 8. septembra 1918, makar formalno, da prihvata misao jugoslovenskog ujedinjenja. ${ }^{3}$ Poslije proglašenja Kraljevstva Srba, Hrvata i Slovenaca 1. decembra 1973), 29.

${ }^{1}$ Милорад Екмечић, Ратни ичивеви Србије 1914 (Београд: Српска књижевна задруга, 1970), 65 .

${ }^{2}$ Dragovan Šepić, Italija, saveznici i jugoslavensko pitanje 1914-1918 (Zagreb: Školska knjiga,

${ }^{3}$ Bogdan Krizman, Vanjska politika jugoslavenske države 1918-1941: diplomatsko-historijski pregled (Zagreb: Školska knjiga, 1975), 6. 
1918, ono se suočavalo sa dva ozbiljna problema: međunarodnim priznanjem i definisanjem granica. Rješavanje ovih pitanja u značajnoj mjeri zavisilo je od Italije, čije su trupe u oktobru iste godine zauzele Dalmaciju, uglavnom do granice određene Londonskim ugovorom iz aprila $1915{ }^{4}$ Ipak, tokom boravka u Dalmaciji, italijanska armija prešla je tu zamišljenu liniju na nekoliko mjesta, u svrhu primjene pritiska tokom Mirovne konferencije u Parizu. ${ }^{5}$ Italijanska nastojanja u Dalmaciji bila su motivisana težnjom za trajnim ostankom na tom području i zadržavanjem oblasti kao sastavnog dijela Italije. U tako ambicioznom planu, borba protiv jugoslovenske države bila je stalno prisutan činilac. Glavni cilj italijanske politike u Dalmaciji bio je usmjeren ka izolaciji ili eliminaciji projugoslovenskih organizacija i ka stvaranju predstave o Italiji kao moćnoj državi. Ipak, raskorak između želja i stvarnosti postepeno je doveo do poraza italijanskih političkih nastojanja u Dalmaciji. ${ }^{6} \mathrm{Na}$ Mirovnoj konferenciji u Parizu (1919-1920), italijanska delegacija zauzela je neprijateljski stav prema jugoslovenskoj delegaciji, s obzirom na činjenicu da je novoproglašena država bila prepreka italijanskim teritorijalnim pretenzijama na istočnu obalu Jadrana i mogućoj italijanskoj dominaciji u jugoistočnoj Evropi. S druge strane, za jugoslovensku delegaciju Italija je bila centar iz kojeg su poticale sve aktivnosti usmjerene ka uništenju Kraljevstva SHS. ${ }^{7}$ Možda je ključna greška u stvaranju italijanske politike prema jugoslovenskoj državi bila u nemogućnosti da se izabere između dva rješenja - posmatrati Kraljevstvo SHS kao saveznika ili kao neprijatelja. ${ }^{8}$

Dvije države sklopile su šest ugovora, uključujući i one u formi konvencija, u periodu od 1920. do 1925. godine: u Rapalu kod Đenove (1920), na Brionima (1921), u Santa Margariti kod Đenove, tj. u Rimu (1923), u Rimu (1924), u Beogradu (1924) i u Netunu kod Rima (1925). Glavna pitanja na koja su se ugovori odnosili bila su: razgraničenje između dvije države, uključujući i status Rijeke, zatim trgovina i plovidba. ${ }^{9}$ Dolazak fašista na vlast u Italiji oktobra 1922. doveo je do određenog napretka u odnosima sa Kraljevinom SHS, zbog nastojanja da nova italijanska vlada učvrsti svoj međunarodni ugled. ${ }^{10}$ Fašistička vlada nije sprovodila radikalnu politiku, ranije obećanu, nastojeći da prikaže italijansku spoljnu politiku kao „novu i dinamič-

${ }^{4}$ Ivo J. Lederer, La Jugoslavia dalla conferenza della paca al trattato di Rapallo 1919-1920 (Milano: Il Saggiatore, 1966), 71.

${ }^{5}$ Mile Bjelajac, ,Talijanske teritorijalne pretenzije u svjetlu vojnog faktora 1918-1920“, Vojnoistorijski glasnik, XXXVII, br. 3, (1986), 203.

'Dragan R. Živojinović, „Italija u Dalmaciji 1918-1920“, Zadarska revija, br. 1-2, (1974), $100-102$.

${ }^{7}$ Andrej Mitrović, Jugoslavija na konferenciji mira 1919-1920 (Beograd: Zavod za izdavanje udžbenika Socijalističke Republike Srbije, 1969), 103.

${ }^{8}$ Paolo Alatri, Nitti, D'Annunzio e la questione adriatica (Milano: Feltrinelli, 1976), 17.

${ }^{9}$ Više o tome u: I documenti per la storia dei rapporti fra l'Italia e la Jugoslavia, a cura di Amedeo Giannini (Roma: Istituto per l'Europa orientale, 1934); Pregled međunarodnih ugovora i drugih pravnih akata od međunarodnopravnog značaja za Jugoslaviju od 1918. do 1941. godine (Beograd: Institut za međunarodnu politiku i privredu, 1962); Vjekoslav Bratulić, „Politički sporazumi između Kraljevine Italije i Kraljevine SHS odnosno Jugoslavije nakon Rapalla“, Jadranski zbornik: prilozi za povijest Istre, Rijeke, Hrvatskog Primorja i Gorskog Kotara, VI/1963-1965, (1966), 5-70.

${ }^{10}$ Luciano Monzali, „La questione jugoslava nella politica estera italiana dalla prima guerra mondiale ai trattati di Osimo (1914-1975)“, Europa adriatica: storia, relazioni, economia, a cura di Franco Botta e Italo Garzia, (Roma - Bari: Laterza, 2004), 24. 
nu“ ${ }^{11}$ Nova vlast se nadala da će Italija imati glavnu ulogu na Balkanu i da će prijateljstvo i saradnja sa jugoslovenskom državom donijeti stabilnost na Balkan i u Podunavlje, istovremeno otvarajući njihova vrata italijanskom političkom, ekonomskom i kulturnom prodoru. Ipak, krajem dvadesetih godina 20. vijeka jugoslovenskoitalijansko prijateljstvo ličilo je na ,zgradu od koje je ostala samo fasada“. ${ }^{12}$

Nasuprot političkim odnosima, koji su obilježeni ozbiljnim suprotnostima i razilaženjima, jugoslovensko-italijanski ekonomski odnosi dvadesetih godina 20 . vijeka bili su veoma razvijeni, prevashodno zbog uzajamnih interesa i komplementarnosti njihovih privreda. Italija je zauzimala prvo mjesto u jugoslovenskom izvozu, a između prvog i četvrtog mjesta u jugoslovenskom uvozu. Međutim, pad u jugoslovensko-italijanskoj trgovinskoj razmjeni postao je očigledan 1926. godine. Italija je pokrivala 20,52\% ukupnog jugoslovenskog uvoza 1924, da bi pet godina kasnije pala na $10,84 \%$. Takođe, Italija je primala $28,91 \%$ ukupnog jugoslovenskog izvoza 1924 , da bi 1929. taj iznos pao na $24,88 \%{ }^{13} \mathrm{U}$ takvim političkim i ekonomskim okolnostima moguće je pratiti i jugoslovensko-italijansko rivalstvo na Jadranskom moru.

Austro-Ugarska je posjedovala 1914. godine trgovačku flotu od 340 brodova, sa 988.790 tona, čiji su vlasnici uglavnom bile kompanije koje su imale sjedište u Trstu (194 broda), Zadru (33) i Dubrovniku (31 brod). Tokom Prvog svjetskog rata (1914-1918), međutim, mnogi od njih su potopljeni ili prodati u Sjedinjene Američke Države. Pitanje podjele austrougarske trgovačke mornarice bilo je jedno od važnijih na Mirovnoj konferenciji u Parizu u novembru 1919. Iako je jugoslovenska delegacija nastojala izdejstvovati da veći broj brodova pripadne novoproglašenoj državi, ona je dobila samo brodove koji su bili u vlasništvu kompanija sa sjedištem u Dubrovniku, dok su Italiji pripali brodovi kompanija sa sjedištem u Trstu i Zadru. Strahujući od snažne italijanske trgovačke flote, a djelimično i od jugoslovenske, što bi moglo ojačati privrednu moć obiju država, Britanija je nastojala da čitavu austrougarsku trgovačku mornaricu stavi na raspolaganje svim saveznicima. ${ }^{14} \mathrm{U}$ italijanskoj vladi procijenjivali su da Kraljevini Srba, Hrvata i Slovenaca realno treba bivših austrougarskih brodova ukupne tonaže između 70.000 i 80.000 tona i da je pretjeran jugoslovenski zahtjev za brodovima od ukupno 250.000 tona. ${ }^{15}$ Sporazum o podjeli austrougarske trgovačke flote između Kraljevine SHS i Italije ratifikovan je u Parizu 7. septembra 1920. ${ }^{16}$ Dvojica ministara, Ante Trumbić i Pjetro Bertolini, dogovorili su se da jugoslovenska država treba da preuzme 135 parobroda sa 114.388 tona, što je činilo svega osminu ukupne tonaže austrougarske trgovačke mornarice. ${ }^{17}$

11 James H. Burgwyn, Italian Foreign Policy in the Interwar Period 1918-1940 (Westport: Greenwood Publishing Group, 1997), 17-18.

${ }^{12}$ Massimo Bucarelli, La Jugoslavia nella politica estera di Mussolini 1924-1937 (Roma: Loreto, 2004) 4,81 .

${ }^{13}$ Goran Latinović, ,Yugoslav-Italian Economic Relations (1918-1929): Main Aspects“, Balcanica, XLVI, (2015), 192.

${ }^{14}$ Archivio centrale dello Stato (ACS), Ministero della marina mercantile - Direzione generale del personale e affari generali (MMM-DGPAG), b. 319, n/19.

${ }^{15}$ ACS, Ministero del tesoro - Direzione generale tesoro (MT-DGT), Ufficio di verifica e compensazione e trattati di pace (UVCTP), el. 12, f. 1.

${ }^{16}$ Arhiv Jugoslavije (AJ), fond 148, Ministarstvo saobraćaja Kraljevine Jugoslavije, fascikla 126.

${ }^{17}$ AJ, zbirka 81, Dobrivoje Stošović, fascikla 1, arhivska jedinica 3. 
Početkom dvadesetih godina 20. vijeka, italijanska pomorska preduzeća poklanjala su veliku pažnju pitanju prevoza jugoslovenskih iseljenika prema Sjevernoj i Južnoj Americi. Gvido Konteso, potpredsjednik kompanije La Navigazione Generale Italiana iz Đenove, doputovao je u Beograd juna 1921, kako bi pokušao da riješi problem u vezi sa koncesijama za transport jugoslovenskih emigranata preko Rijeke. Koncesije, koje je kompanija dobila još od austrougarskih vlasti, više nisu bile na snazi, pa je Konteso pokušao da dobije nove od jugoslovenske vlade, ali nije uspio. Kompanija $L a$ Società Triestina di Navigazione „,Cosulich“ iz Trsta obratila se italijanskoj vladi 29. avgusta 1921. u vezi sa novim jugoslovenskim zakonom o emigrantima, ističući ozbiljno ugrožavanje italijanskih privrednih interesa. Početkom septembra „Cosulich“ se obratio i jugoslovenskoj vladi, tražeći koncesije za prevoz iseljenika. Kompanija se pozvala na konvencije između Srbije i Italije sklopljene 1879, nastojeći da dokaže da su Senžermenskim ugovorom 1919. konvencije proširene na čitavu teritoriju Kraljevine SHS. Tim konvencijama italijanski državljani su dobili pravo da se bave preduzetništvom pod istim uslovima kao i srpski državljani. Ipak, novim zakonom to više nije bilo moguće i jugoslovenske kompanije postale su privilegovane. La Navigazione Generale Italiana iz Đenove obratila se 20. septembra 1921. italijanskom Ministarstvu inostranih poslova, ističući da su sve koncesije, koje je kompanija uživala prije rata, novim jugoslovenskim zakonom ukinute. Njihov predstavnik Eđidio Dagna boravio je u Beogradu i uspio da izdejstvuje određene ustupke. To je dovelo do nove intervencije firme ,Cosulich “, koja se 2. marta 1922. ponovo obratila italijanskim vlastima, a zatim je protestovala i kod jugoslovenske vlade. Istaknuto je da je oko 4.000 južnoslovenskih iseljenika godišnje kretalo ka Americi preko tršćanske luke, a da je taj broj bio i veći prije nego što je Vlada SAD uvela ograničenja u vezi sa useljenjem. Kompanija je očigledno trpjela zbog jugoslovenskog odbijanja da joj dodijeli koncesije. ${ }^{18}$

Firma ,Cosulich“ nije odustajala od svojih zahtjeva, čak ni onda kad je jugoslovenska vlada učinila određene korake ka pronalaženju rješenja. Da „Cosulich“ traži previše, primjetili su i u italijanskom poslanstvu u Beogradu. Odatle je 13. marta 1922. upućen dopis u Rim u kojem je, pored ostalog, skrenuta pažnja na pretjerane zahtjeve tršćanske kompanije, da bi nekoliko dana kasnije italijansko Ministarstvo inostranih poslova bilo obaviješteno o jugoslovenskoj namjeri da zaštiti svoje interese na Jadranskom moru i obezbijedi bolje pozicije pred buduće pregovore. Početkom aprila 1922. u Rim je stigao izvještaj da je „,Cosulich “ potpuno promašio taktiku pregovaranja sa jugoslovenskom vladom. Ipak, kompanija je nastavila da se bori za svoje interese, pa je zahtijevala od italijanske vlade da obustavi sve kredite Kraljevini SHS za kupovinu novih brodova. Istovremeno, La Navigazione Generale Italiana, koja je prethodno dobila koncesije za transport u Južnu Ameriku, željela je da proširi svoj posao i da prevozi iseljenike i u Sjevernu Ameriku. Dok su sve inostrane firme ispunile zahtjeve jugoslovenske vlade i dobile određene koncesije, ,Cosulich“ nije promijenio svoj stav. Italijanski poslanik u Beogradu, Gaetano Manconi, predložio je ovoj kompaniji 5. maja 1922. da bude prilagodljivija. Firma je, međutim, pisala italijanskim vlastima oktobra 1922, žaleći se na italijansko poslanstvo u Beogradu i malu pomoć koju je od

${ }^{18}$ Archivio storico-diplomatico del Ministero degli Affari Esteri (ASDMAE), Archivio del commercio (AC), b. 170, p. 48. 
njega dobila. Ne treba isključiti ni mogućnost da je postojao ,italofobični“ lobi, koji su činili uglavnom Slovenci, a koji je uticao na uporno odbijanje zahtjeva kompanije „Cosulich“. ${ }^{19}$ Ipak, jugoslovenske vlasti kasnile su sa okončanjem postupka za dodjelu koncesija onim kompanijama koje su ispunile sve potrebne preduslove. ${ }^{20}$

La Navigazione Generale Italiana dobila je u februaru 1922. koncesije za prevoz jugoslovenskih iseljenika u Južnu Ameriku, a u junu iste godine i koncesije za njihov prevoz u Sjevernu Ameriku. Kompanija je održavala obje linije, ali iz Đenove i Napulja, sa određenim poteškoćama. Ona je zahtijevala od italijanske vlade 20. februara 1924. da se prema ovim lukama ophodi na isti način kao i prema lukama na Jadranu. $^{21}$ „Cosulich“ se ponovo žalio, predlažući pregovore između dvije vlade, koji bi trebalo da vode ka novom sporazumu koji će omogućiti italijanskim kompanijama da ukrcavaju jugoslovenske iseljenike $u$ italijanskim lukama, a ne samo $u$ jugoslovenskim, što je bio osnovni problem. ${ }^{22}$ Tršćanska kompanija se ponovo obratila italijanskim vlastima 14. jula 1924, obrazlažući da su italijanske luke znatno opremljenije za prijem i prevoz emigranata nego jugoslovenske luke. U pismu je istaknuto da je inostranim kompanijama dopušteno ukrcavanje iseljenika u jugoslovenskim lukama, dok italijanskim nije. ${ }^{23}$ La Navigazione Generale Italiana obavijestila je italijansko Ministarstvo inostranih poslova 11. maja 1925. da je jugoslovensko preduzeće Vesna iz Sušaka, sa parobrodima iznajmljenim od firme Transatlantica Italiana, otvorilo pomorske linije prema Južnoj Americi, ugrožavajući tako poslovanje đenovske kompanije. ${ }^{24} \mathrm{U}$ stvari, rivalstvo između Kraljevine SHS i Italije, odnosno njihovih kompanija, u vezi sa transportom jugoslovenskih iseljenika, bilo je u sjenci rivalstva između italijanskih i zapadnoevropskih prevoznika.

Italijanski kralj Vitorio Emanuele III donio je 17. decembra 1922. dekret o reorganizaciji i subvencijama italijanske trgovačke mornarice, kojim su sve nepotrebne linije ukinute, uključujući i one čije je održavanje ranije uživalo određenu podrš$\mathrm{ku}$, bez obzira na njihovu isplativost. Italijanska vlada davala je godišnje subvencije za održavanje pojedinih linija.

Tabela 1: Godišnje subvencije italijanske vlade kompanijama za pomorski saobraćaj

\begin{tabular}{|l|l|r|}
\hline Kompanija & Linija & \multicolumn{1}{|c|}{ Iznos (u lirama) } \\
\hline Puglia, Bari & $\begin{array}{l}\text { Iz Venecije preko istočnih } \\
\text { jadranskih luka u Bari, } \\
\text { iz Barija u Egej }\end{array}$ & 11.350 .000 \\
\hline Adria, Rijeka & Iz Rijeke u Marsej & 6.000 .000 \\
\hline Istria - Trieste, Trst & Iz Trsta u Zadar & 4.000 .000 \\
\hline Costiera, Rijeka & Iz Rijeke u Trst & 4.000 .000 \\
\hline Tripkovich, Trst & Iz Trsta u Maroko & 2.750 .000 \\
\hline Lloyd triestino, Trst & Iz Trsta u Dubrovnik & 500.000 \\
\hline
\end{tabular}

AJ, fond 65, Ministarstvo trgovine i industrije Kraljevine Jugoslavije, fascikla 241, arhivska jedinica 731

\footnotetext{
${ }^{19}$ Ibid.

${ }^{20}$ ASDMAE, AC, p. 9, s. 9-14.

${ }^{21}$ Ibid.

${ }^{22}$ ACS, MMM-DGPAG, b. 392, t/17 (2).

${ }^{23}$ ASDMAE, AC, p. 3-1-d.

${ }^{24}$ ASDMAE, AC, p. 9, s. 9-14.
} 
Italijanski poslanik u Beogradu Manconi pisao je Ministarstvu inostranih poslova u Rimu 11. marta 1922. da osim riječne flote sa sjedištem u Beogradu (Brodarski sindikat Kraljevine SHS), jugoslovenska država posjeduje i pomorsku trgovačku mornaricu sa tonažom od 200.000 tona, koju čine sljedeće kompanije:

1. Dalmacija, sa 30 parobroda za jadranski saobraćaj,

2. Dubrovačka plovidba, sa 11 parobroda za transport sirovih materijala i dva parobroda za jadranski saobraćaj,

3. Ungaro-Croata, sa 40 parobroda za jadranski saobraćaj i četiri za transatlantski prevoz,

4. Kompanija Račić, sa 10 parobroda za transatlantski prevoz,

5. Oceania, sa osam parobroda za transport i četiri za jadranski servis i

6. Vesna (bez podataka). ${ }^{25}$

Ministarstvo trgovačke mornarice u Rimu posjedovalo je pet godina kasnije preciznije podatke u vezi sa potencijalom jugoslovenskih kompanija.

Tabela 2: Jugoslovenske pomorske kompanije 1927.

\begin{tabular}{|l|l|r|r|}
\hline \multicolumn{1}{|c|}{ Ime i sjedište kompanije } & \multicolumn{1}{|c|}{$\begin{array}{c}\text { Kapital } \\
\text { (u dinarima })\end{array}$} & $\begin{array}{c}\text { Broj } \\
\text { brodova }\end{array}$ & Tonaža \\
\hline 1. Dubrovačka plovidba, Dubrovnik & 40 miliona & 16 & 48.000 \\
\hline $\begin{array}{l}\text { 2. Kompanija za atlantsku plovidbu } \\
\text { Ivo Račić, Split }\end{array}$ & 18 miliona & 11 & 27.000 \\
\hline 3. Oceania, Beograd, Sušak i Trst & 16 miliona & 8 & 30.000 \\
\hline 4. Jugoslavia americana, Split i London & 1,1 milion & 4 & 25.000 \\
\hline 5. Jadranska plovidba, Sušak & 12 miliona & 76 & 32.000 \\
\hline 6. Transoceania, Sušak & 5 miliona & 4 & 16.000 \\
\hline 7. Banac i Rusko, Dubrovnik & nepoznato & 1 & 6.500 \\
\hline 8. Illeria, Zagreb & 4 miliona & 1 & 3.000 \\
\hline 9. Paolo F. Matijević, Split & nepoznato & 1 & 1.000 \\
\hline 10. Boka, Kotor & nepoznato & 5 & 1.000 \\
\hline 11. Ostale male kompanije & nepoznato & 30 & 1.000 \\
\hline
\end{tabular}

ACS, MMM-DGPAG, b. 78, b/37.

Jugoslovenska trgovačka mornarica dostigla je 1928. tonažu od 296.783 tone, a naredne godine Ivo Račić i Jugoslavia americana udružili su se u jednu kompaniju pod imenom Jugoslovenski Lloyd. ${ }^{26}$ U Kraljevini SHS bilo je deset brodogradilišta. ${ }^{27}$

Pomorski saobraćaj na Jadranskom moru bio je važan činilac u jugoslovenskoitalijanskim ekonomskim odnosima dvadesetih godina 20. vijeka. Italijanski konzulat u Splitu poslao je januara 1924. izvještaj u Rim u kojem je rečeno da su tokom prethodne godine italijanski brodovi uplovili u splitsku luku 1.136 puta (532.707 tona), da su utovarili 3.715 .680 kvintala robe i istovarili 314.110 kvintala. Takođe, oni su ukrcali 2.430 putnika, a iskrcali 2.200 ljudi. U izvještaju je još rečeno da je broj

${ }^{25}$ ASDMAE, AC, b. 168, p. 23-9.

${ }^{26}$ AJ, 81-1-3.

${ }^{27}$ Smiljana Đurović, Državna intervencija u industriji Jugoslavije 1918-1941 (Beograd: Institut za savremenu istoriju, 1986), 27. 
jugoslovenskih brodova koji su uplovili u splitsku luku bio veći, ali da je njihova tonaža znatno manja od tonaže italijanskih brodova. Zaključeno je da splitska luka ima poseban značaj za italijansku trgovačku mornaricu. ${ }^{28}$ Iz italijanskog poslanstva u Beogradu upućeno je 7. juna 1924. povjerljivo pismo u Rim, u kojem su italijanske vlasti obaviještene da predstavnici pojedinih italijanskih pomorskih preduzeća $u$ Dalmaciji vrše propagandu i pritisak na vlasnike italijanskih brodova da se za poslovne usluge obraćaju italijanskim, a ne jugoslovenskim kompanijama. ${ }^{29}$ Italijanski konzulat u Zagrebu uradio je 9. jula 1925. uporednu analizu pomorskog saobraćaja kroz Rijeku i susjedni Sušak tokom 1924. Analiza je pokazala da je tokom 1924. oko 400.000 tona robe prošlo kroz riječku luku i oko 163.000 tona kroz Sušak. Uvoz kroz Rijeku iznosio je oko 230.000 tona, a kroz Sušak oko 85.000 tona, dok je izvoz kroz Rijeku iznosio oko 172.000 tona, a kroz Sušak oko 78.000 tona. Italijanski brodovi uvezli su i izvezli kroz obje luke mnogo više nego jugoslovenski i inostrani brodovi zajedno. Italijanski parobrodi uplovili su u Rijeku 988 puta, a u Sušak 72 puta, dok su jugoslovenski parobrodi uplovili u Rijeku 76, a u Sušak 97 puta. ${ }^{30}$ Nadmoć italijanske trgovačke flote nad jugoslovenskom u sjevernom Jadranu bila je sasvim očigledna. Po jugoslovenskim procjenama, 4.024.390 kvintala robe prošlo je kroz Rijeku 1924, što je samo šesti dio predratnog saobraćaja. Tokom 1913. godine 19.051 brod prošao je kroz riječku luku, a 1924. samo 3.946. Iste godine, roba koja je najviše izvožena iz Kraljevine SHS kroz Rijeku bila je drvna građa (109.195 tona), a roba koja je najviše uvožena u jugoslovensku državu bila su mineralna ulja (75.756 tona). ${ }^{31}$

Italijansko poslanstvo u Beogradu poslalo je 29. jula 1926. izvještaj u Rim, u kojem je primijećeno da je Sušak najbolje opremljena jugoslovenska luka i da ima najbolje uslove za veze sa zaleđem. Što se tiče tehničke opremljenosti i saobraćajne povezanosti sa unutrašnjosti jugoslovenske države, sve druge luke (Zelenika u Boki kotorskoj, Šibenik, Split, Metković i Dubrovnik) zaostaju za Sušakom, s tim da ni Sušak nije bez određenih nedostataka. ${ }^{32}$ Šibenik je bivša austrougarska vojna luka, a nalazio se blizu ležišta cementa i rudnika na planini Promini. Split je bio centralna jugoslovenska luka, vodeća u pomorskom saobraćaju i transportu, dok su kroz Metković izvoženi drvni i poljoprivredni proizvodi. ${ }^{33}$

Italijanski konzulat u Dubrovniku obavijestio je 4. septembra 1926. Ministarstvo inostranih poslova u Rimu da je u prvoj polovini te godine 220 italijanskih parobroda (169.225 tona) uplovilo u dubrovačku luku, kao i 117 italijanskih jedrilica (11.372 tone). U poređenju sa istim periodom prethodne godine, uplovilo je 60 parobroda više i šest jedrilica manje. Porast parobroda objašnjen je sedmičnom morskom linijom između Ankone i Dubrovnika, koja je uspostavljena u januaru 1926. Izvještaj je pokazao i to da se u prvoj polovini 1926. u dubrovačkoj luci iskrcalo 1.005 putnika, a 425 ukrcalo, dok je broj putnika u prvoj polovini 1925. iznosio 1.094 iskrcanih i

${ }^{28}$ ASDMAE, AC, p. 4-6, s. 4-10.

${ }^{29}$ ASDMAE, AC, p. 9, s. 9-13.

${ }^{30}$ ASDMAE, AC, p. 9, s. 9-25.

${ }^{31}$ AJ, fond 65, Ministarstvo trgovine i industrije Kraljevine Jugoslavije, fascikla 246, arhivska jedinica 740 .

${ }^{32}$ ASDMAE, AC, p. 10-15, s. 10-11.

${ }^{33}$ AJ, 81-1-3. 
744 ukrcanih. Što se tiče robe, u prvih šest mjeseci 1926. godine 7.442 .972 tone su istovarene iz italijanskih brodova, a 50.855 .794 tone su utovarene. U istom periodu prethodne godine, 4.967.573 tone su istovarene, a 55.913.765 tona je utovareno $\mathrm{u}$ italijanske brodove. Pad utovarene robe od nekih pet miliona tona objašnjen je padom izvoza jugoslovenskog drveta. ${ }^{34}$

Italija je od 1925. do 1927. zauzimala prvo mjesto u jugoslovenskom izvozu morem, primajući polovinu ukupnog jugoslovenskog izvoza morskim putem. U istom periodu, Italija je bila na drugom mjestu u jugoslovenskom uvozu morem, iza Velike Britanije.

Tabela 3: Jugoslovenski izvoz u Italiju morskim putem 1925-1927.

\begin{tabular}{|c|c|}
\hline Godina & Iznos u metričkim centima \\
\hline 1925. & 5.711 .486 \\
\hline 1926. & 6.640 .020 \\
\hline 1927. & 6.949 .101 \\
\hline
\end{tabular}

AJ, 81-1-3

Tabela 4: Jugoslovenski uvoz iz Italije morskim putem 1925-1927.

\begin{tabular}{|c|c|}
\hline Godina & Iznos u metričkim centima \\
\hline 1925. & 860.433 \\
\hline 1926. & 739.780 \\
\hline 1927. & 663.435 \\
\hline
\end{tabular}

AJ, 81-1-3

Što se tiče luka, veći dio jugoslovenskog uvoza prošao je kroz Sušak, a veći dio izvoza kroz Split. Pristajanje italijanskih brodova iz Trsta u jugoslovenske luke, na njihovom putu ka Americi ili oko Afrike, omogućilo je izvoz u mnoge zemlje i kolonije sa kojima Kraljevina SHS nije imala uspostavljene odnose. ${ }^{35}$ Italijanski parobrodi izvezli su iz jugoslovenskih luka znatno više robe nego jugoslovenski parobrodi, pa je preko $70 \%$ ukupnog godišnjeg jugoslovenskog izvoza morskim putem od 1925. do 1927. bilo u rukama italijanske trgovačke mornarice. Stvari su stajale nešto drukčije kad je riječ o jugoslovenskom uvozu, gdje je učešće italijanskih firmi manje, prešavši 40\% samo 1926.

Tabela 5: Učešće italijanskih i jugoslovenskih parobroda u jugoslovenskom izvozu morskim putem 1925-1927.

\begin{tabular}{|l|r|r|r|}
\hline & \multicolumn{1}{|c|}{1925.} & \multicolumn{1}{|c|}{1926.} & 1927. \\
\hline Italijanski parobrodi & $70,8 \%$ & $72,1 \%$ & $71,7 \%$ \\
\hline Jugoslovenski parobrodi & $20,3 \%$ & $19 \%$ & $19,3 \%$ \\
\hline
\end{tabular}

AJ, 81-1-3

Tabela 6: Učešće italijanskih i jugoslovenskih parobroda u jugoslovenskom uvozu morskim putem 1925-1927.

\begin{tabular}{|l|r|r|c|}
\hline & \multicolumn{1}{|c|}{1925.} & 1926. & 1927. \\
\hline Italijanski parobrodi & $34 \%$ & $40,5 \%$ & $35,9 \%$ \\
\hline Jugoslovenski parobrodi & $31,5 \%$ & $41,4 \%$ & $43,4 \%$ \\
\hline
\end{tabular}

AJ, 81-1-3

${ }^{34}$ ASDMAE, AC, p. 9, s. 9-29.

${ }^{35}$ AJ, 81-1-3. 
Nadmoć italijanske trgovačke mornarice u pogledu jugoslovenskog izvoza može biti objašnjena, pored ostalog, i činjenicom da je Italija bila odredište za veliki procenat ukupnog jugoslovenskog izvoza. Takođe, jugoslovenska vlada davala je subvencije uglavnom za pomorski saobraćaj unutar jugoslovenskih granica, dok je italijanska vlada prioritet davala međunarodnim morskim linijama. ${ }^{36}$

U cilju ograničavanja italijanske konkurencije, u jugoslovenskom Ministarstvu trgovine i industrije postojala je ideja u oktobru 1927. da budu uspostavljene slobodne carinske zone u Sušaku, Šibeniku, Splitu i Dubrovniku. Predlagane su dvije mogućnosti: „punto franco“ kao djelimično slobodna luka i „porto franco“ kao potpuno slobodna luka. „Punto franco“ bi predstavljalo određeno mjesto unutar luke gdje bi bili smješteni magacini i depoi za uvezenu robu, koja bi tamo ostala privremeno i koja ne bi bila ocarinjena dok transport ne bude nastavljen. „Porto franco“ bi obuhvatio čitavu luku, čak i grad. Iako su jugoslovenske vlasti odbacile ove ideje, zbog uticaja drugih ministarstava, stručnjaci Ministarstva trgovine i industrije nastavili su da ih razrađuju. ${ }^{37}$

Ministarstvo trgovačke mornarice u Rimu primilo je u martu 1929. informacije o uspostavljanju nove pomorske kompanije u Sušaku pod imenom Slobodna plo$v i d b a$, sa početnim kapitalom od 500.000 dinara. Takođe, italijanska vlada obaviještena je da je Jugoslovenski Lloyd kupio novi brod pod imenom Tomislav, da Jadranska plovidba iz Sušaka želi da kupi 18 novih parobroda i da je Dubrovačka plovidba već kupila dva parobroda od kompanije Tripkovich iz Trsta, oba od 107 tona. ${ }^{38}$

Iako je pomorski saobraćaj između dvije jadranske obale i transport ljudi i robe imao posebno mjesto u jugoslovensko-italijanskim ekonomskim odnosima, razni problemi su se povremeno javljali. Jugoslovensko poslanstvo u Rimu saznalo je u novembru 1922. da italijanske vlasti ne prihvataju dozvole koje su jugoslovenske vlasti izdavale jugoslovenskim parobrodima, zbog čega su protestovali kod italijanske vlade, optužujući je za nepoštovanje međunarodnog pomorskog prava. U stvari, nesporazum je započeo italijanskom inspekcijom jugoslovenskog parobroda Slavni Špiro u Barleti kod Barija 25. septembra $1922 .{ }^{39} \mathrm{~S}$ druge strane, lučke vlasti u Šibeniku, Splitu i Dubrovniku bile su obavezne, u vezi sa plaćanjem taksi, da se ophode prema italijanskim brodovima na isti način kao i prema jugoslovenskim. U aprilu 1923, međutim, italijanski poslanik u Beogradu, Lacaro Negroto Kambiaso, protestovao je zbog narušavanja tog pravila. ${ }^{40}$ Kompanija Puglia - Società Anonima di Navigazione e Vapore iz Barija žalila se 1. decembra 1924. zbog odluke lokalne policije u Dubrovniku da svaki brod koji uplovi u dubrovačku luku izvan radnog vremena mora da plati određenu kaznu. Koliki je bio značaj pomorskog saobraćaja između dvije države jasno se vidi upravo na ovom primjeru, jer su italijansko Ministarstvo inostranih poslova, Ministarstvo trgovačke mornarice i Poslanstvo u Beogradu intervenisali tokom decembra 1924. i januara 1925, kako bi problem bio prevazi-

\footnotetext{
${ }^{36}$ Isto.

37 AJ, 65-246-740.

${ }^{38}$ ACS, MMM-DGPAG, b. 392, t/17 (2).

${ }^{39}$ AJ, fond 373, Poslanstvo Kraljevine Jugoslavije u Italiji, fascikla 5, arhivska jedinica 8.

${ }^{40}$ AJ, fond 148, Ministarstvo saobraćaja Kraljevine Jugoslavije, fascikla 123.
} 
đen. ${ }^{41}$ Italijanski parobrod Ninfa bio je zadržan punih sedam sati radi carinske kontrole u Sušaku 29. maja 1925, pa je protestovao njegov kapetan Macola. ${ }^{42}$ Sredinom jula 1926, Udruženje za ribolov i poljoprivredu iz Veneta pisalo je italijanskoj vladi zbog nekoliko incidenata između njihovih ribolovaca i jugoslovenskih lokalnih vlasti na području Raba i Paga, da bi narednog mjeseca u Rim stigla informacija o novim incidentima na istom području, u kojima su učestvovala italijanska plovila Conte Rosso, Conte Verde, Vanda i Corallino. ${ }^{43}$ Italijanski konzulat u Sušaku obustavio je izdavanje viza jugoslovenskim mornarima u martu 1929, pa je uslijedio recipročan jugoslovenski odgovor. ${ }^{44}$ Nekoliko jugoslovenskih kompanija zahtijevalo je od jugoslovenske vlade u maju 1929. da izvoz drveta u Italiju bude potpuno u rukama domaćih firmi, dok je Trgovačka komora iz Dubrovnika upozorila jednog preduzetnika da je njegovo korišćenje italijanskih parobroda za poslove uvoza i izvoza protivno jugoslovenskim privrednim interesima. U Rimu su ove aktivnosti okarakterisane kao jugoslovenska propaganda protiv italijanske trgovačke mornarice. ${ }^{45}$

$*$

Prema tome, italijanska prevlast bila je sasvim očigledna u jugoslovenskoitalijanskom pomorskom rivalstvu na Jadranskom moru od 1919. do 1929. godine. Italijanska trgovačka mornarica bila je znatno razvijenija od jugoslovenske, i po broju brodova i po tonaži, dok su italijanske luke bile opremljenije od jugoslovenskih. Prednost Italije bila je i u činjenici da su joj pripadale najznačajnije luke i na istočnoj obali Jadrana, Trst i Rijeka (od 1924), i da su obje bile veoma dobro povezane željezničkim putem sa Srednjom Evropom. Mogućnost transporta ljudi i robe morskim putem imala je izuzetan uticaj na jugoslovensko-italijanske ekonomske odnose u naznačenom periodu, a italijanske pomorske kompanije držale su primat u jugoslovensko-italijanskoj trgovinskoj razmjeni pomorskim putem. O tome jasno govori i podatak da je preko 70\% ukupnog godišnjeg jugoslovenskog izvoza morskim putem od 1925. do 1927. bilo u rukama italijanske trgovačke mornarice, koja je pokrivala i znatan procenat ukupnog jugoslovenskog uvoza. Rivalstvo između dvije zemlje nastavljeno je i nakon 1929, ali je i dalje bilo obilježeno italijanskom dominacijom.

\section{IZVORI I LITERATURA}

- Arhiv Jugoslavije (AJ), fond 65, Ministarstvo trgovine i industrije Kraljevine Jugoslavije; zbirka 81, Dobrivoje Stošović; fond 148, Ministarstvo saobraćaja Kraljevine Jugoslavije; fond 373, Poslanstvo Kraljevine Jugoslavije u Italiji.

- Archivio centrale dello Stato (ACS), Ministero della marina mercantile - Direzione generale del personale e affari generali; Ministero del tesoro - Direzione generale tesoro, Ufficio di verifica e compensazione e trattati di pace.

\footnotetext{
${ }^{41}$ ASDMAE, AC, p. 9, s. 9-14.

${ }^{42}$ ASDMAE, AC, p. 9, s. 9-29.

${ }^{43}$ ASDMAE, AC, p. 16-27, s. 17-12.

${ }^{44}$ AJ, 373-5-8.

${ }^{45}$ ACS, MMM-DGPAG, b. 392, t/17.
} 
- Archivio storico-diplomatico del Ministero degli Affari Esteri (ASDMAE), Archivio del commercio.

- I documenti per la storia dei rapporti fra l'Italia e la Jugoslavia, a cura di Amedeo Giannini. Roma: Istituto per l'Europa orientale, 1934.

- Pregled međunarodnih ugovora i drugih pravnih akata od međunarodnopravnog značaja za Jugoslaviju od 1918. do 1941. godine. Beograd: Institut za međunarodnu politiku i privredu, 1962.

- Alatri, Paolo. Nitti, D’Annunzio e la questione adriatica. Milano: Feltrinelli, 1976.

- Bjelajac, Mile. „Talijanske teritorijalne pretenzije u svjetlu vojnog faktora 19181920“. Vojnoistorijski glasnik, XXXVII, br. 3, (1986), 197-208.

- Bratulić, Vjekoslav. „Politički sporazumi između Kraljevine Italije i Kraljevine SHS odnosno Jugoslavije nakon Rapalla“. Jadranski zbornik: prilozi za povijest Istre, Rijeke, Hrvatskog Primorja i Gorskog Kotara, VI/1963-1965, (1966), 5-70.

- Bucarelli, Massimo. La Jugoslavia nella politica estera di Mussolini 1924-1937. Roma: Loreto, 2004.

- Burgwyn, James H. Italian Foreign Policy in the Interwar Period 1918-1940. Westport: Greenwood Publishing Group, 1997.

- Đurović, Smiljana. Državna intervencija u industriji Jugoslavije 1918-1941. Beograd: Institut za savremenu istoriju, 1986.

- Екмечић, Милорад. Ратни цииљеви Србије 1914. Београд: Српска књижевна задруга, 1973.

- Krizman, Bogdan. Vanjska politika jugoslavenske države 1918-1941: diplomatskohistorijski pregled. Zagreb: Školska knjiga, 1975.

- Latinović, Goran. „Yugoslav-Italian Economic Relations (1918-1929): Main Aspects“. Balcanica, XLVI, (2015), 171-194.

- Lederer, Ivo J. La Jugoslavia dalla conferenza della paca al trattato di Rapallo 1919-1920. Milano: Il Saggiatore, 1966.

- Mitrović, Andrej. Jugoslavija na konferenciji mira 1919-1920. Beograd: Zavod za izdavanje udžbenika Socijalističke Republike Srbije, 1969.

- Monzali, Luciano. „La questione jugoslava nella politica estera italiana dalla prima guerra mondiale ai trattati di Osimo (1914-1975)“. Europa adriatica: storia, relazioni, economia, a cura di Franco Botta e Italo Garzia, Roma - Bari: Laterza, 2004, 15-72.

- Šepić, Dragovan. Italija, saveznici i jugoslavensko pitanje 1914-1918. Zagreb: Školska knjiga, 1970.

- Živojinović, Dragan R. „Italija u Dalmaciji 1918-1920“. Zadarska revija, br. 1-2, (1974), 98-120. 
Goran Latinović

\author{
YUGOSLAV-ITALIAN MARITIME RIVALRY \\ AT THE ADRIATIC SEA 1919-1929
}

\begin{abstract}
Summary
The Italian domination was quite evident in Yugoslav-Italian rivalry at the Adriatic Sea from 1919 to 1929. Italian merchant fleet was much more developed than Yugoslav, both by number of ships and by their tonnage, while Italian ports were better equiped than Yugoslav. The adventage of Italy was also in the fact that it owned the most important ports on eastern Adriatic coast, Trieste and Rijeka/Fiume (since 1924), and that both were very well connected by railroads to Central Europe. The possibility of transport of people and goods by sea had exceptional influence on Yugoslav-Italian economic relations in that period, with Italian maritime companies holding the primacy in the trade exchange between the two countries. Over $70 \%$ of all Yugoslav export by sea from 1925 to 1927 was in the hands of Italian merchant fleet, which also covered significant percentage of all Yugoslav imports. The rivalry between the two countries continued after 1929, and it was also characterized by the Italian domination.
\end{abstract}

KEYWORDS: The Kingdom of Serbs, Croats and Slovenes, Italy, rivarly, the Adriatic sea, the trade echange, merchant marine, sea and port traffic

\title{
LA RIVALTÀ MARITTIMA JUGOSLAVO-ITALIANA SUL MARE ADRIATICO 1919-1929
}

\section{Sommario}

Il predominio italiano era completamente evidente nella rivaltà jugoslavoitaliana sul mare Adriatico dal 1919 al 1929. La marina italiana mercantile era notevolmente più sviluppata da quella jugoslava, sia per il numero di navi sia per il tonnellaggio, mentre i porti italiani erano meglio attrezzati rispetto a quelli jugoslavi. Il vantaggio dell'Italia è stato anche nel fatto che a lei appartenevano i più importanti porti sulla costa orientale dell'Adriatico, Trieste e Fiume (dal 1924), e che entrambi erano molti ben collegati tramite la ferrovia con l'Europa centrale. La possibilità di trasporto di persone e di merce via mare ha avuto un'influenza eccezionale sulle relazioni economiche jugoslavo-italiane nel periodo specificato, mentre le compagnie marittime italiane hanno mantenuto la loro supremazia nel commercio jugoslavoitaliano marittimo. Questo è chiaramente illustrato dal fatto che oltre il $70 \%$ delle esportazioni marittime jugoslave annuali dal 1925 al 1927 erano nelle mani della marina mercantile italiana, che copriva una percentuale significativa di tutte le importazioni jugoslave. La rivaltà tra i due paesi ha continuato dopo il 1929, però è stata sempre caratterizzata dalla dominazione italiana.

PAROLE CHIAVE: Il Regno dei Serbi, Croati e Sloveni, l'Italia, la rivaltà, il mare Adriatico, il commercio, la marina mercantile, il traffico marittimo e portuale 